\title{
Physical integrity: the missing link in biological monitoring and TMDLs
}

\author{
Brenda Asmus • Joseph A. Magner • \\ Bruce Vondracek • Jim Perry
}

Received: 24 March 2008 / Accepted: 5 November 2008 / Published online: 14 January 2009

(C) US Government 2009

\begin{abstract}
The Clean Water Act mandates that the chemical, physical, and biological integrity of our nation's waters be maintained and restored. Physical integrity has often been defined as physical habitat integrity, and as such, data collected during biological monitoring programs focus primarily on habitat quality. However, we argue that channel stability is a more appropriate measure of physical integrity and that channel stability is a foundational element of physical habitat integrity in low-gradient alluvial streams. We highlight assess-
\end{abstract}

The Minnesota Cooperative Fish and Wildlife

Research Unit is jointly sponsored by the US

Geological Survey, the University of Minnesota, the

Minnesota Department of Natural Resources, and the

Wildlife Management Institute.

B. Asmus (ه)

Water Resources Science Program,

University of Minnesota, 1980 Folwell Avenue,

St. Paul, MN 55108, USA

e-mail: asmus024@umn.edu

\section{J. A. Magner · J. Perry}

Department of Fisheries, Wildlife, and Conservation

Biology, University of Minnesota,

1980 Folwell Avenue, St. Paul, MN 55108, USA

B. Vondracek

Minnesota Cooperative Fish and Wildlife Research

Unit, US Geological Survey and University

of Minnesota, 1980 Folwell Avenue,

St. Paul, MN 55108, USA ment tools that could supplement stream assessments and the Total Maximum Daily Load stressor identification process: field surveys of bankfull cross-sections; longitudinal thalweg profiles; particle size distribution; and regionally calibrated, visual, stream stability assessments. Benefits of measuring channel stability include a more informed selection of reference or best attainable stream condition for an Index of Biotic Integrity, establishment of a baseline for monitoring changes in present and future condition, and indication of channel stability for investigations of chemical and biological impairments associated with sediment discontinuity and loss of habitat quality.

Keywords Channel stability • Sediment • Biotic impairment • Low-gradient alluvial streams $\cdot$ Habitat assessment

\section{Introduction}

The objectives outlined in the 1972 Clean Water Act and its amendments (PL 92-500, Section 101[a]) require that the "physical, chemical, and biological integrity" of our nation's waters be maintained and restored. Many of the terms within the Clean Water Act amendments were not explicitly defined, and as a consequence, water quality managers and researchers have 
struggled with defining these terms for regulatory and management activities (Cairns 1977; Frey 1977; Karr 1981, 1993; Karr and Dudley 1981; Hughes et al. 1982; Aadler 1995; Whittier et al. 1987; Barbour et al. 2000). The increased attention to Total Maximum Daily Loads (TMDLs) associated with biotic impairment now requires water quality managers and researchers to reflect and ask important questions, such as: Is our present definition sufficient to protect physical integrity as well as biological and chemical integrity of streams? If not, how should physical integrity be defined and assessed?

We propose that physical integrity be equated with channel stability and that channel stability is an integral component of physical habitat integrity in low-gradient alluvial streams. We argue that channel stability is the missing link in water quality monitoring programs and TMDL investigations of biotic impairments. To remedy this missing link, we highlight a suite of physical and visual assessments that could be used to assess channel stability. As a result, chemical, physical, and biological integrity would be better understood, protected, and restored.

Are we monitoring physical integrity?

Graf (2001) asserted that water quality managers and researchers have focused on the chemical and biological integrity of streams, whereas physical integrity has been overlooked or ignored. This oversight may be the result of the lack of a formal definition of physical integrity in the original Clean Water Act. As a consequence, many water quality managers and researchers have chosen to define and monitor physical integrity in terms of physical habitat integrity (Reid and Hilton 1998; Goldstein et al. 1999; Rabeni 2000; Bauer and Ralph 2001). But can and should physical integrity be defined only in terms of physical habitat? Is this approach sufficient to monitor physical integrity and to ensure that the physical structure and function of stream ecosystems is maintained?

Physical integrity defined

We use the term physical integrity to imply a consistency of structure and function of the physical attributes of a watercourse through time. This definition is consistent with that of Graf (2001) who offered the following definition for the term:

"Physical integrity for rivers refers to a set of active fluvial processes and landforms wherein the channel, flood plains, sediments, and overall spatial configuration maintain a dynamic equilibrium, with adjustments not exceeding limits of change defined by societal values." (Italics inserted by authors for emphasis)

Graf's (2001) definition of physical integrity is similar to definitions of channel stability (e.g., Lane 1955; Rosgen 1996; Watson et al. 2002).

Lane (1955) defines channel stability as "the dynamic equilibrium that exists between stream power and the discharge of bed material sediment." This equilibrium concept is generally described by the following relationship (Lane 1955; sensu Rosgen 1996)

$Q_{\mathrm{s}} D_{50} \sim Q S$

where equilibrium is maintained or achieved when there is a balance between the product of the current discharge $(Q)$ and stream gradient (i.e., slope, $S$ ) and the product of sediment discharge (i.e., bed material load, $Q_{\mathrm{s}}$ ) and median particle size of bed material sediment $\left(D_{50}\right)$. In other words, channel stability is achieved when there is a balance between the scouring forces of flow (volume and velocity) and resistance to flow (degree of hydraulic shear stress due to sediment type and volume of mobilized sediment).

A similar definition for this equilibrium concept is provided by Rosgen (1996, p. 7-11) who defined channel stability as:

"the ability of the stream, over time, to transport the flows and sediment of its watershed in such a manner that the dimension, pattern and profile of the river is maintained without either aggrading nor degrading."

Watson et al. (2002) provided a similar definition as Lane (1955) and Rosgen (1996). Watson et al. (2002) described channel stability as a function of sediment continuity (i.e., sediment supply is balanced by the sediment transport capacity). When the sediment transport capacity is greater 
than the sediment supply, sediment will be eroded from the channel banks and bottom (depending on the resistance of the bed and bank materials); when the sediment supply is greater than the sediment transport capacity, suspended sediment will settle out and aggrade the channel bed (Magner and Brooks 2007).

The definition that we accept for physical integrity is the same as definitions given for physical integrity by Graf (2001) and channel stability by Lane (1955), Rosgen (1996), and Watson et al. (2002). This definition for physical integrity is generally not used; one exception is by the Arizona Department of Environmental Quality, Monitoring and Assessment Program (http://www.azdeq. gov/environ/water/assessment/ongoing.html). We argue that physical integrity is synonymous with channel stability (i.e., hydrologic, hydraulic, or geotechnical stability and sediment continuity); it is the foundational element that supports habitat quality in low-gradient alluvial streams and streams with erodable cohesive sediments. Thus, channel stability is a necessary ingredient for the support of optimal habitat quality.

Relationships among physical integrity, habitat quality, and stream biota

The structure and function of the physical stream is governed by the interaction between geomorphology and hydrology (Fig. 1, Maddock 1999). The interaction among landform, surficial geology, and discharge creates the structural form of the channel that in turn governs the volume and quality of the aquatic habitat (Maddock 1999). This relationship dictates the type and kind of suitable habitat available for biotic organisms (e.g.,

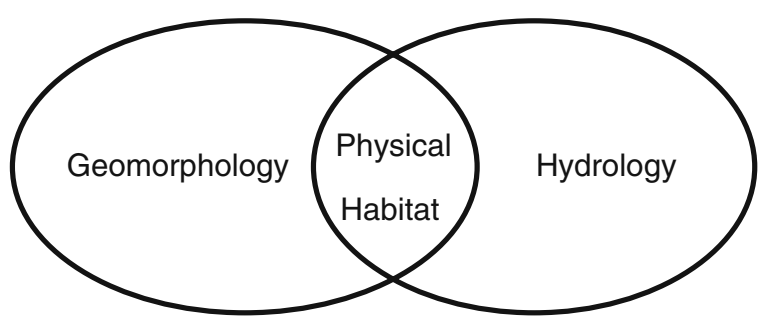

Fig. 1 Stream physical habitat is determined by the interaction between channel geomorphology and hydrology. Figure modified from Maddock (1999) substrate type, riffles and pools, flow variability, degree of embeddedness). Geomorphic condition (e.g., sinuosity, gradient, channel shape, crosssectional area, substrate size) has also been shown to influence diversity and productivity of fish communities (Berkman and Rabeni 1987; Waters 1995; Sullivan et al. 2006). Fish and macroinvertebrate functional groups are confined by water depth and velocity (Gorman and Karr 1978), as well as the availability, size, and sorting of substrates suitable for reproduction, feeding, and protection (Allan 1975; Karr and Chu 1999). When the stream channel is stable (i.e., not eroding or aggrading above expectation), the stream is able to maintain its form and structure, and therefore, the stream, according to the definition we propose, demonstrates that it has physical integrity.

The resulting dynamically stable physical channel form provides the foundation upon which other elements of habitat are arranged (e.g., vegetation, large woody debris) and biological communities are structured (Southwood 1977; Ross et al. 2001). Large woody debris, riparian and in-stream vegetation, and depth variability contribute to the heterogeneity of the habitat that supports biological diversity. Hence, habitat assessments typically focus on the presence of these physical elements (i.e., physical habitat) since biological potential is dependent on the quality of the habitat (Rabeni 2000). However, most habitat assessments only record the presence of these habitat elements (e.g., substrate size, woody debris, riffles, pools). What is typically not assessed is whether or not these structures were recently mobilized by high flow events, the degree of floodplain connectivity, and the ability of the stream to maintain riffle/pool complexes, thalweg depth, and stable banks during annual high flow events. A stream that is not able to maintain these stream features will have a reduced potential to support a diverse biological community.

Fish and macroinvertebrates depend on specific habitats; a loss of habitat diversity can result in a loss of biotic diversity (Gorman and Karr 1978; Maul et al. 2004; Lau et al. 2006). For example, stream channelization reduces habitat diversity through removal of meander bends and in-stream vegetation (Lau et al. 2006) that creates uniform bed morphology (Brookes 1988) 
and altered flow regimes (Karr and Dudley 1981). Excess sediment that enters streams as a result of poor land use practices and unstable banks can embed or cover coarse substrates that are required by organisms for reproduction, feeding, and protection (Waters 1995; Nerbonne and Vondracek 2001; Berkman and Rabeni 1987). Increased embeddedness of coarse substrates reduces habitat area and results in reduced macroinvertebrate density (Lenat et al. 1981). Altered flow regimes may lead to degradation of habitat (e.g., high flows, mobility of coarse substrates, low flows, sedimentation) and water quality impairments that further impact biota.

Fundamentally, if there is change in the hydrologic regime (e.g., increased peak flows due to change in vegetative cover on the landscape) or change in sediment transport capacity (i.e., ability of stream to handle sediment load without aggrading), channel adjustment will be initiated (sensu Lane 1955), and the physical structure and biological function of the stream channel and its attendant floodplain will change. Consequently, habitat degradation and water quality impairments will occur and biotic communities will be affected. Thus, the fundamental interaction among geomorphology (geology, channel morphology, and substrate size), hydrologic pathway (movement of water to the channel), and hydraulic forces (shear stress) forms the physical structure upon which habitat is developed (Maddock 1999). Theoretically, habitat quality will be at its optimum when watershed hydrology and stream sediment transport capacity are in balance within the context of regional geology, land use, and natural climate fluctuation. Conversely, when substrate supply and the flow regime are out of balance, e.g., as could occur when changes in land use increase storm flow peaks (maximum discharge), the channel will undergo a period of instability during which habitat quality is diminished (e.g., excess scouring, embeddedness, loss of floodplain connectivity, loss of deep pool refugia). Therefore, we define the combination of habitat structures (i.e., physical habitat) and the structural and hydrologic stability of the channel (i.e., physical integrity) as physical habitat integrity. In our view, most habitat assessments do not adequately assess channel stability.
Habitat assessments used in biological monitoring programs in the USA

In the USA, habitat assessments have routinely been employed during regular biological water quality monitoring programs to assess river health (Karr and Dudley 1981; Karr 1999; Maddock 1999). Some of the more commonly used assessments include the Qualitative Habitat Evaluation Index (QHEI; Rankin 1989), the Rapid Habitat and Visual Reach Assessment (Barbour et al. 1999), and quantitative habitat assessments to reduce subjective bias (e.g., Sorenson et al. 1999). In general, these assessments evaluate local land use, riparian health, dominant sediment class per unit area, degree of embeddedness, bank erosion, variation in stream features, and cover for fish and macroinvertebrates. However, while these assessments characterize habitat types and quality of habitat available for aquatic biota, in our opinion, they do not stress the fluvial processes that control channel stability, which we argue is foundational to maintaining habitat quality and stream health, especially in low-gradient streams typical of the Midwestern USA. While national stream assessment protocols that include more quantitative assessments of geomorphic channel condition have been developed (e.g., Fitzpatrick et al. 1998; Kaufmann and Robison 1998), these assessments are generally not used by most state biological monitoring programs (Goodrich et al. 2004). Perhaps, these geomorphic assessments have been perceived as difficult for some state agencies to implement for various reasons, such as additional field time and personnel costs, pressure to assess more streams in a shorter time-period, adequate training for field crews, equipment costs, and perceived lack of utility. However, TMDL investigations of biological and chemical stream impairments may soon change this perception.

TMDLs and limitations with habitat assessments

During condition monitoring (i.e., initial biological monitoring to assess stream health), a stream that does not meet water quality standards associated with its designated use (e.g., human consumption, aquatic recreation) is considered impaired and added to the Federal 303(d) list 
of impaired water bodies. Each listed reach, or identified Assessment Unit (AUID), requires completion of a TMDL assessment to identify the stressor(s) linked to the impairment (USEPA 2000a). Additional monitoring may by needed to target and identify suspected stressors, which may include continuous chemical monitoring, flow measurements, habitat assessments, and geomorphic condition assessments. The ultimate goal of a TMDL is to reduce loading of identified stressors associated with the listed impairment and subsequently return the AUID to compliance with water quality standards and designated uses.

When a stream is listed for impaired biota, previously collected chemistry and habitat data can be analyzed to tentatively identify potential stressors associated with the impairment (e.g., low dissolved oxygen (DO), turbidity, lack of cover, substrate embeddedness). If the pollutant is excess stream sediment, a habitat assessment may provide an indication of potential sources of sediment from unstable stream banks or local land use practices (Vondracek et al. 2005) such as cattle grazing in the riparian zone (Trimble and Mendel 1995). Unfortunately, other stressors associated with unstable channels, such as bed scouring and substrate mobility, (Pfankuch 1975) are not quantified by most habitat assessments, although these conditions have been associated with habitat instability (Death and Winterbourn 1995) as a consequence of channel instability (Tipton et al. 2004). Additionally, the geomorphic condition of the channel as being either incised and disconnected from the floodplain or overwidened and a potential cause of aggradation is not generally assessed. Consequently, most habitat assessments do not provide sufficient evidence that a channel is hydrologically, hydraulically, or geotechnically unstable; as such, the underlying mechanism that may impact habitat and biota may not be identified. Therefore, we argue that there is a missing link in many state biological assessment protocols currently in use in the USA.

Channel stability: the missing link

Water chemistry, habitat quality, and channel stability all are important drivers of biological integrity. As such, all three are required to main- tain the ecological integrity of streams. Maddock (1999) asserted that river health should be evaluated based on water quality, hydrology, geomorphology, and availability of physical habitat including assessments that measure flow regime and assess conditions of channel stability. Kaufmann (1993) and Kaufmann et al. (1999) identified and described seven stream attributes that influence stream ecology: channel dimensions, channel gradient, channel substrate size and type, habitat complexity and cover, riparian vegetation cover and structure, channel-riparian interaction, and anthropogenic alterations; an observed or measured change in any of these physical attributes can be used to detect an anthropogenic disturbance. At present, most condition monitoring programs generally assess water chemistry, habitat quality, and structure of the biotic community (Fig. 2); however, it is not common to conduct a separate assessment of channel stability [i.e., the stream's ability to

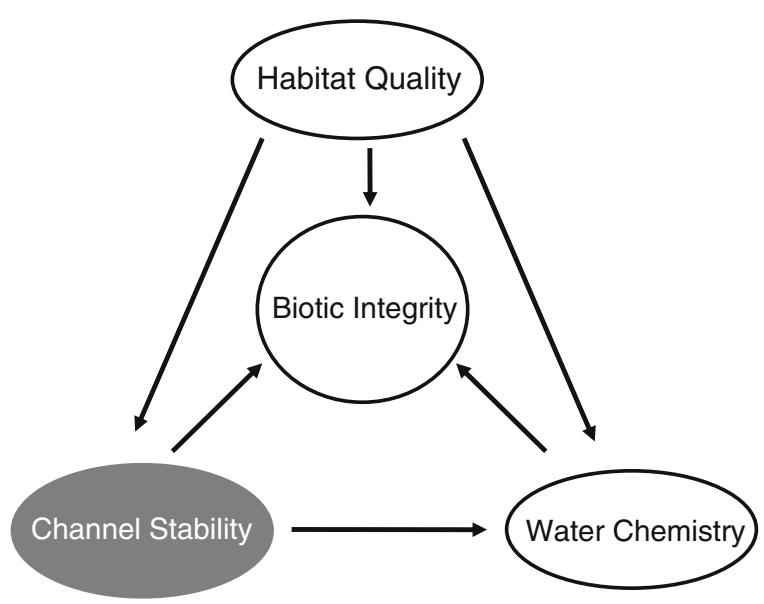

Fig. 2 Diagram illustrating an initial TMDL stressor identification process for impaired biota. White circles represent the typical data collection strategy employed by most state biological monitoring programs, while the gray circle represents channel condition and stability assessments that may be a missing link that would enhance the initial stressor identification process. A more focused assessment of channel stability (i.e., ability to maintain geomorphic shape and resist erosional forces) will identify stressors related to a sediment imbalance (sediment size and quantity) or changes in flow regime (sediment discontinuity) resulting in correctly prescribed remediation efforts. In our view, all components are needed to adequately assess the ecological integrity of low-gradient alluvial streams and address biological impairments 
maintain its channel structure through assessing whether a balance between sediment (size and quantity) and the flow regime (sediment transport competence) is presently being achieved]. Consequently, state regulators who address sediment TMDLs are faced with a lack of information on channel geomorphic, hydraulic, and geotechnical conditions that would help identify mechanisms leading to sediment discontinuity, habitat degradation, and biological or chemical impairment. Determining the mechanisms of impairment is crucial to designing targeted and realistic remediation efforts. Channel stability assessments are the missing link in biological monitoring programs and TMDL investigations of sediment discontinuity (Fig. 2). We suggest that an increased understanding of channel geomorphic, hydraulic, and hydrologic processes by biological monitoring crews and supplementing habitat assessments with qualitative and/or quantitative measures channel stability will remedy this missing link.

\section{Natural stream processes verses} channel instability

Natural stream processes are determined largely by climate, geology, vegetation, and basin morphology (Petts and Foster 1985); consequently, characterization of the stream's natural sediment and flow regime may vary widely by region and geologic stream type. In this paper, we focus our discussion on the natural stream processes of degradation and aggradation that are typical for mid- to low-gradient alluvial streams (Lane 1955; Schumm 1977) and streams that contain cohesive silts and clays, particularly in the streambank. Alluvial streams naturally undergo dynamic processes of degradation and aggradation within a watershed network from headwater streams to large rivers at such slow rates and quantities that changes in stream character are not readily perceptible (Simon and Rinaldi 2000). These processes fluctuate temporally (i.e., wet season to dry season, annual variation), spatially (i.e., lateral migration), and stochastically (e.g., large floods or droughts).

The balance among these natural shifts in sediment production and sediment transport capacity (Lane 1955) i.e., sediment continuity, is consid- ered the stream's stable state (quasi-equilibrium; Simon 1989) within its current geology, land use, and climate (Rosgen 1996). In contrast, channel instability is defined as an imbalance between sediment production and sediment transport capacity (i.e., sediment discontinuity). Instability results from a combination of sources that involve both natural events and anthropogenic changes (Simon and Downs 1995; Simon and Rinaldi 2000). Exmples of natural events that initiate channel instability in low-gradient alluvial streams includethe following: glacial rebound, also referred to as uplift or subsidence (Schumm 1977; Riedel et al. 2005); knickpoint migration between lowland rivers and higher elevation headwaters; and meander cutoffs that periodically occur in sinuous channels (Hooke 2004). Natural channel adjustment processes can be accelerated and magnified by human activities (Table 1), such as mechanical alteration, or indirectly through activities that change watershed hydrology (Simon and Downs 1995), as could occur due to changes in vegetation (Anderson et al. 2006), increases in impervious area, and hydrologic alterations induced by climate change (Poff et al. 1996; Rapport et al. 1998). Altered climate and landscape conditions can lead to a change in the magnitude, timing, and duration of peak flows (Rosgen 1996) subsequently initiating periods of channel instability and adjustment (Simon and Downs 1995).

Channel instability: impacts to stream habitat, chemistry, and biota

Annual peak stream flow events and sediment mobility are considered important natural disturbances essential to maintaining healthy biological communities (Resh et al. 1988; Allan 1995). Periodic disturbances, such as floods, can benefit habitat conditions for biota (Allan 1995). Occasional higher flows have more erosive power to scour away fines embedding substrates and pools, overbank flows introduce large woody debris (Kline et al. 2004) and organic matter (Cuffney 1988) from riparian corridors. Biological communities are largely adapted to occasional disturbances that are part of the natural cycle of streams (Allan 1995); however, when the magnitude and frequency of disturbance is 


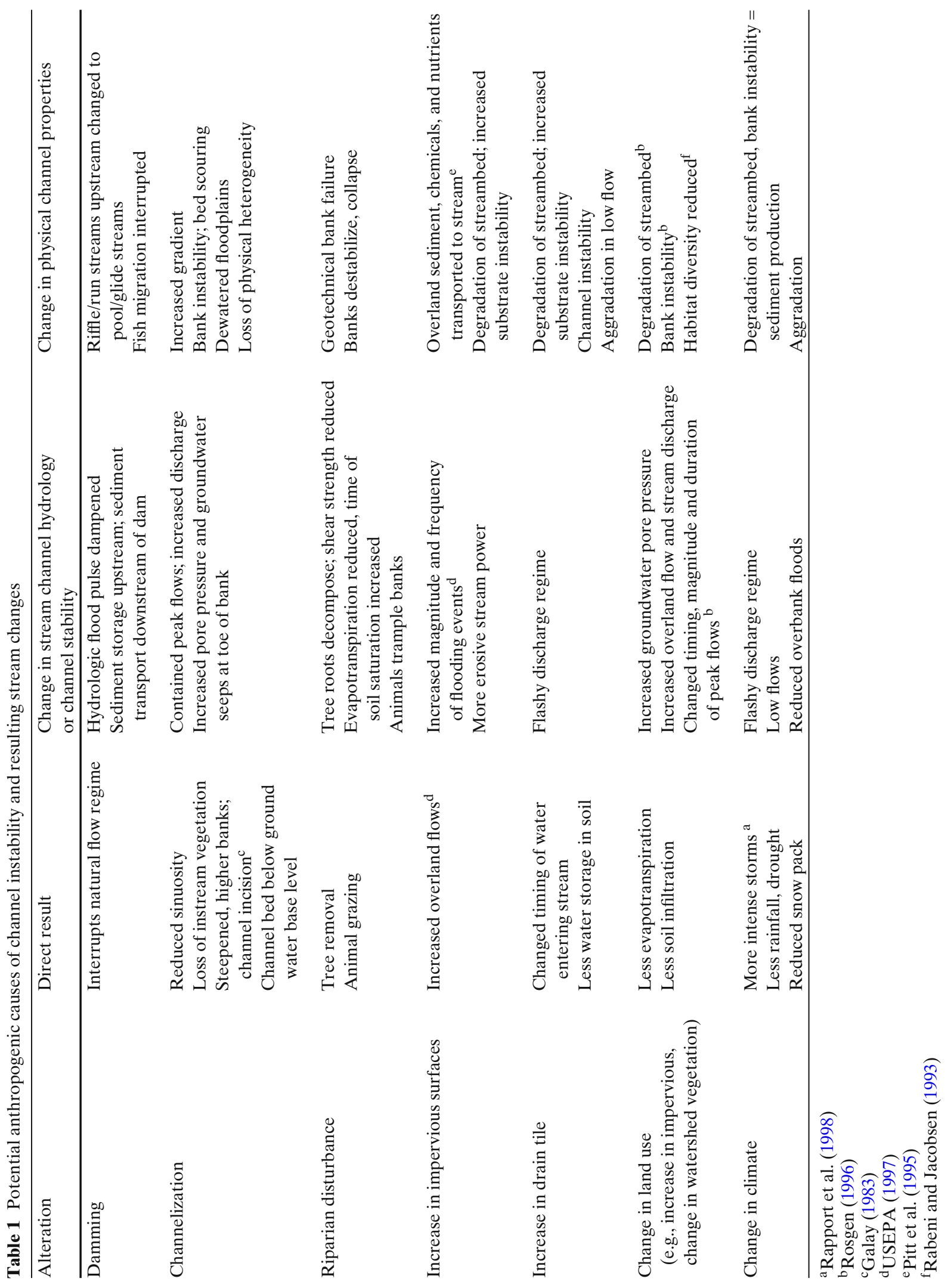


altered, a threshold is breached after which biological communities may be negatively impacted (Connell 1978; Townsend et al. 1997a). Periods of drought, water diversion, or reductions in annual snowmelt may interrupt the annual periodicity of scouring flows to remove fines embedding coarse substrates thereby impacting lithophilic spawners (Brouder 2001). Anthropogenic channel alterations and changes in watershed hydrology (Table 2) can accelerate and magnify the intensity of disturbance and initiate system-wide disequilibrium (Schumm et al. 1984; Simon 1989; Simon and Rinaldi 2000; Ross et al. 2001; Magner et al. 2004b; Lenhart 2008) during which channel geomorphic changes may occur (e.g., channel incision, widening, aggradation) and habitat quality and biological integrity may be affected.

Incision, also referred to as downcutting or bed-level lowering, often follows an increase in sediment transport capacity (i.e., increased stream discharge) above mean annual sediment supply (Lane 1955; Galay 1983; Magner et al. 2004b). Processes of downcutting and channel widening can cause long-term changes in the structure and function of stream channels and riparian corridors (Shields et al. 1994); subsequently, habitat and biotic degradation occur (Table 2). Incising channels disconnect from their floodplains (Schumm et al. 1984; Thorne et al. 1997; Watson et al. 2002), consequently reducing low flow refuge for youngof-the-year fish and weak swimmers during high discharge events (Junk et al. 1989). Annual high flows that used to spill out into the floodplain are now concentrated within the deeper channel profile thereby magnifying the degree of degradation or bottom scouring. As a result, larger substrates upon which organisms rely for reproduction, feeding, and protection are now mobilized, thereby causing a reduction in species diversity (Death and Winterbourn 1995) and density (Death and Winterbourn 1995; McIntosh 2000). Floodplain systems attenuate nutrients delivered from overbank flows (Forshay and Stanley 2005); when the channel is incised and disconnected from its floodplain, excess nutrients can cause or exacerbate water quality issues. Incised stream banks tend to evolve by hydraulic toe slope erosion and subsequent geotechnical failure resulting in excess instream sediment and loss of habitat heterogeneity through infilling of pools and interstitial spaces. Aggradation in pools can result in greatly reduced pool depth, thereby limiting the availability of late-summer and over-winter refugia for large fish (Schlosser 1987). Excessive sediment delivery from unstable banks can trigger violations of numeric water quality standards for chemical impairments [e.g., total suspended solids (TSS), turbidity, temperature, low dissolved oxygen] and narrative standards (biotic integrity) leading to CWA Section 303(d) listing of streams (Lenhart 2008). Hence, when substrate supply or the stream's hydrology experience an imbalance (e.g., hydrologic discharge is increased), the channel undergoes a period of instability during which habitat and water quality is suboptimal and potentially limiting to certain species of fish and macroinvertebrates. In contrast, when the natural dynamic equilibrium is in balance, physical habitat and water quality is theoretically at its optimum and will support a more diverse and stable biological community (Maul et al. 2004).

Sources of sediment to streams: overland soil erosion and unstable channels

In several National Water Quality Reports to Congress, sediment has frequently been listed as one of the leading causes of water quality impairment for stream reaches assessed in the USA (USEPA 1990, 1992, 1995, 1998, 2000b, 2002, 2007). Brooks et al. (2003, p. 211) stated that excess sediment can "adversely affect water quality and aquatic habitat and is one of the primary targets of the TMDL provisions of the Clean Water Act in the USA." Excess sediment in streams is traditionally perceived as primarily the result of land use practices causing overland or gully erosion (Waters 1995). However, excess sediment can also be the result of unstable stream channels (Brooks et al. 2003). A number of studies (NRCS 1988; Trimble 1997; Simon et al. 2006) that partitioned sediment sources between upland and channel erosion reported that contributions from unstable banks and stream beds dominated the sediment budget and that this sediment source was the main cause of declining water quality in downstream receiving waters. Specifically, Simon et al. (2006) reported that 
Table 2 Stages of the channel evolution model (Schumm et al. 1984; Thorne et al. 1997) with descriptions of the associated channel condition and theoretical impacts to biota [conditions considered beneficial $(+)$ or detrimental (-) to fish and/or macroinvertebrates]

\begin{tabular}{ll}
\hline CEM stage/Process & Channel condition \\
\hline I. Sinuous, premodified & $\begin{array}{l}\text { Heterogeneous channel bottoms; deep pools, } \\
\text { shallow edge habitat, backwaters }\end{array}$ \\
& $\begin{array}{l}\text { Floodplain connectivity = energy of peak } \\
\text { annual flows dissipated into floodplain }\end{array}$
\end{tabular}

II. Degradation

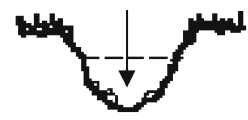

III. Degradation and widening

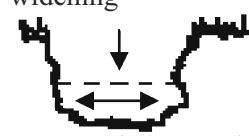

IV. Aggradation and widening

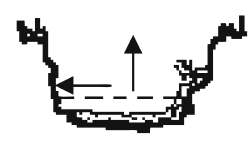

V. Quasiequilibrium

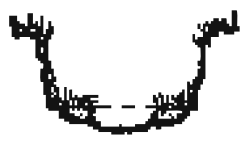

Loss of flood plain connectivity $=$ fewer overbank flows into flooplain

Increased channel capacity $=$ increased shear stress during channel forming flows

Scouring $=$ mobilization of stable substrates and macrophytes

Mass wasting, bank erosion, increased sediment supply $=$ increased turbidity, increased temperature and reduced dissolved oxygen

Velocity reduced, suspended sediments settle and embed coarse substrates

Pool infilling and loss of habitat heterogeneity Sediment bars at bends build up and divert flow to outer bank causing bank collapse

New channel forms in aggraded sediment; reintroduced floodplain within channel

Trees and plants root in freshly deposited alluvial sediment and stabilize banks

Narrower channel cuts into aggraded aggraded sediment, pools deepen, bottom complexity returns
Impact to biota

$(+)$ presence of refugia during spates benefits young-of-year and weak swimmers

$(+)$ reproductive zone for floodplain adapted species

$(+)$ overwintering pools benefit large fish; supports trophic complexity

$(+)$ for nutrient limited streams, nutrient recharge from floodplains $=$ periphyton growth that supports algal grazers; for streams receiving excess nutrients, floodplain attenuation limits excessive plant growth $=$ normal DO flux.

$(-)$ loss of refugia for young-of-year and weak swimmers during spates

$(-)$ increased macroinvertebrate drift; increased mortality

(-) for nutrient limited streams, periphyton growth limited = reduced food supply for grazers; for streams receiving excess nutrients, plant growth increases $=$ increased DO fluxes and potential for low DO.

(-) loss of stable substrates and macrophytes; impacts reproduction, rearing, feeding, protection

$(-)$ loss of diversity and abundance

$(-)$ irritated gill tissues, respiratory and feeding stress

$(-)$ increased drift; decreased abundance

$(-)$ loss of sensitive species $=$ loss of species diversity

(-)reduced reproductive success of lithophilic spawners

$(-)$ loss of food availability for grazers, scrapers, and net builders

(-)loss of interstitial spaces used for protection

(-) loss of deep overwintering pool refuge; loss of habitat for large fish $=$ trophic level impacts

(-) high flows still concentrated within terraces of former channel; harsher flood-flow conditions for biota than original channel

(+) for nutrient limited streams, nutrients from floodplain = supports periphyton growth and bottom-up tropic complexity; for streams receiving excess nutrients, floodplain attenuation $=$ stabilized DO fluxes.

$(+)$ new refuge during spates; overwintering

(+) trophic complexity returned

(+) species diversity returned, abundance returned

Dashed lines on figures indicate height of channel forming flow; arrows indicate direction and magnitude of base-level change (degradation or aggradation) or bank retreat. Figures modified from Bledsoe et al. (2002) after Schumm et al. (1984). 
fine-grained sediment emanating from unstable stream banks was responsible for declining water quality in Lake Tahoe. Trimble (1997) reported that two thirds of the sediment budget for San Diego Creek was from channel erosion, and a report by the Natural Resources Conservation Service (NRCS 1988) indicated that unstable stream banks in the lacustrine portion of the Nemadji River Basin contributed up to $89 \%$ of the sediment transported into Lake Superior.

Physical indicators of unstable channels

After instability is initiated, changes in the dimension, pattern, and profile of streams can be observed (Rosgen 1996) and "characteristics and conditions of the channel bed, channel banks, accumulation of debris and other causes of flow deflection, and the condition of riparian vegetation" can be used as diagnostics of channel stability/instability (Simon and Downs 1995). In addition, changes in bed material size and computations of hydraulic forces at bankfull conditions can also be used to assess transport capacity and infer channel instability (Lisle et al. 2000).

Temporal changes in channel morphology and hydraulic stability have been described (i.e., Channel Evolution Model, Schumm et al. 1984; Incised Channel Evolution Model, Simon 1989; Channel Stability Diagram, Watson et al. 2002). However, physical indicators of channel evolution and hydrologic instability (e.g., headcut migration, scouring, coarse substrate mobility, undercut banks, intermittently receding channel banks, and loss of floodplain connectivity) are largely ignored during biological assessments.

\section{Channel stability assessments}

There are several assessments available to monitor channel stability using physical indicators (e.g., Stream Reach Inventory and Channel Stability Evaluation, Pfankuch 1975; Channel Instability Index, Simon and Downs 1995; Streambank Erosion Hazard Index, Near-Bank Stress, Rosgen 1996). The US Environmental Protection Agency (USEPA) and US Geological Survey (USGS) assess geomorphic condition by measuring crosssections, longitudinal profiles, and pebble counts for national stream assessment programs (e.g., Environmental Monitoring and Assessment Program of the USEPA, Kaufmann and Robison 1998; Peck et al. 2006; National Water Quality Assessment Program of the USGS, Fitzpatrick et al. 1998).

The USEPA recently developed a standardized methodology for systematically linking sediment issues to watershed processes and to assess stream channel stability called the Watershed Assessment for River Stability and Sediment Supply (WARSSS; Rosgen 2006). While WARSSS provides an in-depth analysis of channel stability related to present and future sediment supply to rivers and streams from bank and channel erosion, this level of detail requires training in watershed hydrology and fluvial geomorphology. The entire WARSSS procedure may be considered too laborious during an initial Phase I (condition monitoring) watershed assessment since each level of a WARSSS assessment can take weeks to months to complete and validate. However, some elements of the WARSSS procedure collected during a Phase I assessment could provide information as a preliminary screening tool for planning a Phase II (TMDL stressor identification) assessment.

Channel stability assessments and water quality monitoring programs

Stream managers should consult and consider existing habitat assessments that include more detailed assessments of channel stability (e.g., Fitzpatrick et al. 1998; Kaufmann and Robison 1998). Several components of these and other channel stability assessment techniques are discussed below. Depending on the limitation of time and resources, a few of these assessments could supplement existing water quality monitoring programs during an initial Phase I assessment; the information collected could assist in determining the type and level of data collection required during a Phase II stressor identification process (USEPA 2000a). The additional time required to complete these assessments largely depends on the type and number of assessments, number of personnel, stream size, reach length, and complexity of the stream channel. Harrelson et al. (1994) describe field methods 
for establishing benchmarks and measuring crosssections and longitudinal thalweg profiles; Peck et al. (2006) describe how to conduct instream measurements of channel cross-sections, longitudinal thalweg profiles, and a modified pebble count procedure that together with measurements of woody debris can be used to assess relative bed stability (RBS; Kaufmann et al. 2008); and Rosgen (2006) outlines applications of both subjective and qualitative channel morphology assessments in Phase II stream stability analysis.

\section{Channel cross-section}

The channel cross-section provides information for calculating channel dimensions and assessing channel condition (e.g., degree of incision and/or overwidening, floodplain connectivity). Generally, bankfull width to depth ratio $\left(W_{\mathrm{bf}} / D_{\mathrm{bf}}\right)$, crosssectional area (CSA), and entrenchment ratio (ER; ratio of floodprone width to bankfull width) are used to assess channel condition, transport capacity, and stability (Rosgen 1996; Montgomery and MacDonald 2002; Watson et al. 2002).

Because the channel forming flow is presumed to correspond to the bankfull discharge (Wolman and Leopold 1957), channel width and depth are often used for interpreting and monitoring channel condition (Montgomery and MacDonald 2002) and for computing ratios used for the Rosgen Classification (Rosgen 1996). The height of the channel-forming discharge (i.e., effective discharge, Wolman and Leopold 1957) is often difficult to identify in the field when channels are unstable (Simon et al. 2007), and bankfull indicators are not readily apparent e.g., because of bare banks due to geotechnical failure (Magner and Brooks 2007, 2008). Uncertainty in the estimation of bankfull height can be resolved by using regional hydraulic geometry curves (RHGCs; Leopold and Maddock 1953). These curves are log-log plots that compare bankfull channel crosssectional dimensions (i.e., bankfull width, mean bankfull depth, CSA) versus drainage area (DA; NRCS 2007).

RHGCs are developed by first determining the bankfull or channel forming flow (i.e., generally 1.2 to 1.8 recurrence interval flow) using discharge measurements from gage stations with at least 10 years of consecutive data (USGS 1982). Magner and Brooks (2007) describe how separate curves should be developed for regions with similar climate, landscape terrain, land use, geology, and watershed hydrology. The National Water Management Center (NWMC) is collaborating with local, state, and federal agencies to develop RHGCs throughout the USA. See currently available RHGCs at http://wmc.ar.nrcs.usda.gov/ technical/HHSWR/Geomorphic/ (NRCS 2007).

Once developed or obtained, RHGCs can assist in in-stream estimations of bankfull height using the empirically derived CSA and DA. When possible, the RHGC-derived estimate of bankfull height should be validated with local observations of bank features such as a change in slope, perennial vegetation, and depositional features (Harrelson et al. 1994; Peck et al. 2006) within or just upstream or downstream of the surveyed reach. However, after debris torrents or major floods, these features may have been scoured away and will not be readily apparent (Peck et al. 2006). In this case, an undisturbed stream with the same drainage area, geology, and climate may be used to validate the expected cross-sectional area. A relatively accurate estimate of bankfull is required to compute sediment competence; however, if the goal of the assessment is only to infer whether or not the stream is connected to its floodplain, overwidened and aggradating, or is incised [see Figs. 7, 8 and 9 in Peck et al. (2006) for schematics of floodplain connected and incised streams], the RHGC-derived CSA will provide a relative estimation of the expected bankfull flow height.

\section{Longitudinal thalweg profile}

A longitudinal profile determines bed and water surface elevation over a given stream length (e.g., 20 to 30 times the channel bankfull width). A longitudinal profile can also be used to record field indicators of bankfull elevation and pool sediment deposition that can provide information about channel adjustment. Observation of changes in the bed profile (i.e., increase or decrease in thalweg depth variability, changes in pool and riffle spacing) and local changes in channel slope provide information about bed stability and sediment 
transport. If multiple years of data are available, movement of a knickpoint (i.e., a sharp point of change in channel slope) may suggest that the channel is evolving to a new morphology. A knickpoint will migrate upstream until the upstream and downstream gradients within the reach are similar (Brooks et al. 2003) or until the knickpoint encounters a resistant substrate. Further, if the depth of unconsolidated sediment in the streambed is also recorded during the profile, the degree of pool infilling or bottom scouring can be assessed (Lisle and Hilton 1999).

A longitudinal profile also provides a localized estimation of stream gradient. As a general practice, stream gradient is estimated from topographic maps with contour lines of known elevations. In regions with relatively flat terrain, the distance between known topographic changes can fall outside the reach of interest; consequently, the gradient is estimated over a larger distance. This can result a gradient estimation that may not accurately characterize the gradient of the localized surveyed reach. By collecting a fieldderived longitudinal profile, the reach-level gradient estimations may be more accurate; however, careful field surveying is necessary to get good estimates of gradient in low-relief systems. Stream gradient estimations also provide information on unit stream power and the associated boundary shear stress acting upon the bed and banks of the channel. This information can be used to assess the sediment transport competence (Kaufmann et al. 1999, 2008) and sediment transport capacity for initial departure analysis (Rosgen 2006).

\section{Particle size distribution}

In sand, gravel, or mobile-bed streams, the particle size distribution in the stream channel can be estimated by a Wolman pebble count (Wolman 1954) or sieve analysis (Lambe 1951). A pebble count is performed by random selection and measurement of the median diameter of 100 sediment particles over the study reach; particle diameters are graphically plotted to determine the portion of particles that are finer than the 50th percentile $\left(D_{50}\right)$ and 84th percentile $\left(D_{84}\right)$ of the sampled particles. For streams that are dominated by finegrained sediments, a sieve analysis may be prefer- able. A sediment sample is collected from multiple points along the reach; after drying, the sample is sorted through a nested set of progressively finer sieves (Lambe 1951). The weights of each sediment partition are graphed as a percent of the total sample weight against diameter size (sieve opening size). The $D_{50}$ and $D_{84}$ are often used to evaluate channel geometry hydraulics, e.g., shear stress and associated sediment continuity. Thus, changes in particle size ranges may indicate an imbalance in sediment supply or sediment transport capacity.

In contrast to a pebble count, most commonly used habitat assessments visually characterize the dominant substrate type of the stream bed at 4 to 5 points across a transect; an estimation of percent embeddedness of coarse substrates is often also recorded. While this procedure is useful for determining the dominant substrate types available for stream biological potential and habitat quality (e.g., clean gravel for lithophilic spawners), fine sediments (silt, sand, gravel) may be underrepresented, and may not provide indication that the stream sediment transport capacity has changed. In contrast, a Wolman pebble count characterizes the full range of substrate sizes encountered, including non-dominant substrates. Changes in mean particle size of the streambed may be driven by sediment discontinuity; if a channel bed aggrades or degrades, something within the system (e.g., sediment supply or discharge) has been altered.

Assessment of channel condition using field measurements and computations

Together, the cross-section, longitudinal profile, and particle size distribution can be used to compute hydraulic properties at bankfull, including boundary shear stress. Boundary shear stress provides an estimate of the forces acting on the channel bank and bed during bankfull conditions (Lisle et al. 2000). Software programs are available to compute channel dimensions and hydraulic properties (e.g., STREAM Module, http:// www.dnr.state.oh.us/tabid/9188/default.aspx; RIVERMorph ${ }^{\circledR}$, http://www.bossintl.com/html/ rivermorph_overview.html). Montgomery and MacDonald (2002) described of how channel 
dimensions and bankfull hydraulic forces can be used to diagnose channel condition. Kaufmann et al. (2008) describe how to characterize regional expectations of RBS with which to compare and diagnose sedimentation issues related to anthropogenic disturbance. This level of detail may be more appropriate for the Phase II stressor identification investigation than for general condition monitoring; however, a record of geomorphic variables collected during condition monitoring could benefit the TMDL process (see "Benefits of channel stability assessments").

Information about the entrenchment ratio (ER) can assist in identifying and validating the current state of stream channel stability by classifying the stream evolutionary stage, as an example, a stream is considered moderately entrenched (i.e., channel confined by landform slope) when the ER is between 1.4 and 2.2 (Rosgen 1996). This stream would be considered incised and classified as Stage II in the Channel Evolution Model (Table 2). In such a condition, energy from higher discharges is contained and magnified within a narrower area compared to a stream that was not incised. This confinement at high flow promotes channel Evolution Processes of incision (i.e., downcutting and floodplain disconnection) and/or channel widening (i.e., bed is armored and downcutting is limited).

\section{Stream Reach Inventory and Channel Stability Evaluation}

The Stream Reach Inventory and Channel Stability Evaluation (Pfankuch 1975), hereafter referred to as the Pfankuch Stability Index (PSI), has been used for numerous applications from stream condition assessment, international research, and stream restoration. The PSI is a tool used in the USEPA WARSSS procedure (Rosgen 2006) to assess stream channel condition and stability for watershed assessment and TMDL problem investigations. The PSI has also been used extensively in international research investigating relationships between channel stability and biota (Rounick and Winterbourn 1982; Death and Winterbourn 1994, 1995; Townsend et al. 1997b; Duncan et al. 1999; Robertson and Milner 1999; McIntosh 2000; Gislason et al. 2001; Lods-Crozet et al. 2001a, b; Maiolini and Lencioni 2001; Heiber et al. 2002). The PSI has also been used to evaluate streambanks for restoration by the Izaak Walton League of America (IWLA 2006). However, this tool is not normally used for biological monitoring programs in the USA (Goodrich et al. 2004). This may in part be due to the lack of familiarity of biologists with the PSI, or that the utility of this additional assessment tool for biological monitoring programs has not yet been realized.

The PSI was developed in mountainous streams in the western USA (Pfankuch 1975). Several modifications to the PSI have been suggested to extend its applicability to other stream types and to test specific research questions. Rosgen (1996) has devised a score modification procedure using his stream classification to better characterize potential and future stability of streams based on substrate character and geomorphic variables. Research assessing habitat stability (as indicated by mobility of coarse substrates) utilized PSI metrics associated only with the channel bottom (see Death and Winterbourn 1994; Death 1995; Winterbourn and Collier 1987; McIntosh 2000; Castella et al. 2001). Current research evaluating the utility of the PSI to predict fish IBI in low-gradient streams in Minnesota suggests that modifications to the original PSI should be considered for these systems (Asmus et al., unpublished data). For example, some Midwestern streams appear to be dominated by alluvial non-cohesive stream banks where groundwater discharge and internal pore pressure have destabilized noncohesive alluvium at the toe of the bank, resulting in bank failure (Magner et al. 2004a); these conditions are not characterized by the current PSI. Modification to the current PSI could be considered to tailor this assessment tool to more accurately assess channel stability in different stream settings.

In its most basic form, the PSI can be used as a preliminary screening tool to assess channel condition and aid in determining whether a more quantitative assessment may be required. After regional calibration and validation, the PSI may offer a time-efficient and effective qualitative assessment tool that could be used in tandem with subjective habitat assessment tools such as the QHEI (Rankin 1989). 
Benefits of channel stability assessments

Channel stability assessments could be beneficial to watershed assessment programs in a number of ways, including: (1) aiding in selection of reference or best attainable stream condition for developing metrics for an IBI, (2) providing a baseline for monitoring changes in present and future condition, and (3) providing descriptive and empirical documentation of channel conditions with which to aid TMDL problem investigations of chemical and biological impairments associated with excess sediment or a reduction in sediment transport capacity.

\section{Selection of reference streams during IBI development}

Determining and defining the reference condition is a critical element in biocriteria development (Barbour et al. 2000). During IBI metric development, channel stability assessments can be used for selection of stable reference sites (Maul et al. 2004). Maul et al. (2004) found that macroinvertebrate communities in stable streams demonstrated less temporal variability than communities collected from intermediate and highly unstable channels. Characterizing streams as "stable" or "adjusting" relative to regional expectations may help explain some of the variability often found among candidate reference streams during IBI development. Explaining this variability could improve the definition of a best attainable stream condition for a particular region and stream type.

\section{Establishing a baseline for monitoring changes}

Establishing a permanent benchmark allows direct comparison of a cross-section and longitudinal profile through time (Harrelson et al. 1994). Permanent benchmarks and cross-sections often are required for field assessments and validation of channel stability. These benchmarks may vary from official USGS elevation monuments on bridges to other structures such as telephone poles, building foundations, and rock outcrops in streams. Photographs taken from a consistent location and perspective can also be useful for observing changes in channel condition. Field evidence of changes in channel characteristics could signal that the flow or sediment regime has changed (Rosgen 1996) and has set in motion a period of potential channel instability that requires remedial action. Aptly targeted remediation strategies during the early stages of channel evolution may prevent system-wide degradation.

\section{Channel stability and TMDLs}

TMDL problem investigations of the causal mechanisms of excess suspended and bedload sediment (Rosgen 2006) will likely require additional data collection, including assessments of channel stability (e.g., WARSSS, Rosgen 2006). One of the issues that may confound a determination of channel stability is that, often, these assessments are collected one or more years after the reach was listed as an impaired waterbody. Therefore, the mechanisms originally responsible for sediment discontinuity may no longer be active (Anderson et al. 2006), as could occur when a disturbed alluvial channel has evolved to more stable channel morphology (Schumm et al. 1984; Rosgen 1996; Simon 1989; Watson et al. 2002). Consequently, an investigation may not identify the source of sediment discontinuity that existed at the time of 303(d) listing, causing investigators to target incorrect sources for remediation. In addition, assessments of channel stability are often considered incomplete until future assessments are available with which to make a comparison and validate channel instability. If channel geomorphic measurements and channel stability assessments were taken at the time of biological monitoring, these fluvial assessments could provide an historical record with which to diagnose channel instability and prescribe remediation strategies. Rehabilitation alternatives should also be assessed within the context of the spatial variability and temporal succession of channel evolution (Watson et al. 2002). Therefore, we suggest that assessments of channel morphology be included during biological monitoring to improve future TMDL investigations of impairments and for selecting aptly targeted load allocations and associated remediation strategies. 
A history of turbidity and the Minnesota River

Historically, the Minnesota River has been a turbid system; the Dakota named the river Minne sota, or cloudy water (Upham 1969). In the early 1990s, high levels of TSS, nutrients, and visibly turbid waters were perceived to be the consequence of large-scale agricultural practices within the basin, inspiring the governor at the time to promote basin-wide efforts to clean up the Minnesota River within a 10-year timeframe (Feist and Niemala 2002). Government agencies and landowners collaborated to reduce surface and gully erosion by enrolling thousands of hectares in federal and state conservation easement programs and promoting best management practices, such as grass swales, riparian buffers, and conservation tillage. A follow-up study by the Minnesota Pollution Control Agency (Feist and Niemala 2002) found that although improvements in biotic integrity were found in the headwaters of the basin, there was little change in the basin overall. The minimal change in biological condition observed was attributed primarily to increases in tile drainage, ditching, and urbanization within the basin over the intervening time period. In addition, researchers have proposed several alternate causes and mechanisms for the continued high levels of TSS and turbidity in the Minnesota River (Magner and Steffen 2000; Hatch et al. 2001; Bauer 1998; Thoma et al. 2005). Magner and Steffen (2000) argued that extensive landscape transformation (e.g., loss of wetlands, increased tile drainage, change in vegetation) over the last century increased the occurrence of peak stream flows and initiated a period of channel adjustment. Hatch et al. (2001) suggested that streambank erosion might be a significant contributor. Thoma et al. (2005) argued that geotechnical failure from alluvial soil layering and pore pressure seeps above the waterline continually destabilize non-cohesive alluvial bluffs (Bartholomew and Gupta, unpublished data, http://a-c-s.confex.com/ crops/2006am/techprogram/P23551.HTM). Bauer (1998) suggested that post-glacial knickpoint migration in the Blue Earth River is a historical but gradually decreasing supply of sediment to the Minnesota River (Mulla and Bauer, unpub- lished data, http://a-c-s.confex.com/crops/2006am/ techprogram/P27313.HTM ).

Clearly, identification of historical, natural, and anthropogenic mechanisms of sediment discontinuity is crucial to complete a successful TMDL. Best management practices that do not target the cause of hydraulic, geotechnical, or hydrologic imbalances that lead to channel instability may provide limited benefit. Unless the suite of mechanisms for sediment discontinuity is identified, costly remediation efforts may result in minor improvements (Brezonik et al. 1999)—or even make the situation worse (Watson et al. 2002).

\section{Olentangy River Watershed TMDL}

The Olentangy River Watershed TMDL (Ohio EPA 2007) is an example of an interdisciplinary framework that incorporates knowledge of biology, chemistry, fluvial geomorphology, and watershed hydrology in attempt to address biological impairments. Leading causes of impairment identified in the TMDL were habitat alteration, nutrient enrichment, flow alteration, and siltation. The TMDL suggests that remediation strategies include cattle exclusion from riparian zones, improving channel stability and water quality through two-stage ditch construction, restoring floodplain connectivity, increasing watershed storage of overbank flows, and increasing infiltration, among others. These measures are intended to benefit the biological community by attenuating nutrients and stabilizing DO, dampening peak flows and increasing base-flows, and improving habitat conditions by reducing siltation through stream bank stabilization and retention of sediment by riparian floodplains. This TMDL incorporates an interdisciplinary understanding of processes at the scale of reach, riparian, and watershed; all scales may be necessary to successfully address TMDLs related to biological impairments.

\section{Conclusion}

Changes in hydrology, morphology, and subsequent sediment continuity can alter and impair 
physical habitat, water chemistry, and biota. We suggest that biotic communities in low-gradient alluvial systems would be better managed and protected if physical integrity was defined as channel stability and that channel stability was clearly incorporated into the definition of physical habitat integrity. Physical integrity is an important foundational mechanism or missing link in maintaining biotic integrity, and channel stability is an important dimension of physical habitat integrity that is necessary for maintaining "the chemical, physical and biological integrity of our Nation's waters" (CWA Section 101[a]). Inclusion of stability assessments during IBI development will better identify reference reaches, provide a baseline for future assessments of channel condition changes, and provide an understanding of potential fluvial processes that underlie biotic impairment during TMDL investigations. An in-depth understanding of channel stability and other aspects of fluvial geomorphology is important for bridging the knowledge gap that may often exist between biologists and geomorphologists involved in assessing waters impaired by unstable stream channels. Successful completion of TMDL problem investigations will require an understanding of processes operating at different scales within the watershed and may involve collaboration and integration of multiple disciplines involving biology, chemistry, geomorphology, and watershed hydrology. We recommend that channel stability and other fluvial geomorphic and hydrologic and hydraulic assessments occur during biological monitoring and TMDL investigations to distinguish between natural and human-induced variability in IBI scores and to meet the mandate of the Clean Water Act to protect and restore physical integrity.

Acknowledgements We thank David E. Andersen, Richard L. Kiesling, and John Swartz who read an earlier draft of this manuscript and provided thoughtful and constructive comments. We also thank an anonymous reviewer who edited the manuscript and offered suggestions that better defined the scope of this article and increased clarity. This paper was written in support of a broader research project funded by the United States Protection Agency and the Minnesota Pollution Control Agency. Although the research described in this article has been funded wholly or in part by the United States Environmental Protec- tion Agency through grant/cooperative agreement RD83136601-1 to the University of Minnesota, it has not been subjected to the Agency's required peer and policy review and therefore does not necessarily reflect the views of the Agency and no official endorsement should be inferred.

\section{References}

Aadler, R. W. (1995). Filling the gaps in water quality standards: Legal perspectives on biocriteria. In W. S. Davis, \& T. P. Simon (Eds.), Biological assessment and criteria: Tools for water resource planning and decision making. Boca Raton, LA: Lewis.

Allan, J. D. (1975). The distributional ecology and diversity of benthic insects in Cement Creek, Colorado. Ecology, 56, 1040-1053. doi:10.2307/1936145.

Allan, J. D. (1995). Stream ecology: Structure and function of running waters. New York, NY: Chapman \& Hall.

Anderson, J., Baratono, N., Streitz, A., Magner, J. A., \& Verry, E. S. (2006). Effect of historical logging on geomorphology, hydrology, and water quality in the Little Fork River Watershed. St. Paul, MN: Environmental Outcomes and Regional Environmental Management Divisions, Minnesota Pollution Control Agency.

Barbour, M. T., Gerritsen, J., Synder, B. D., \& Stribling, J. B. (1999). Rapid bioassessment protocols for use in wadeable streams and rivers: Periphyton, benthic macroinvertebrates and fish. EPA-841-B-99-002 (2nd edn.). Washington, DC: Office of Water, US Environmental Protection Agency.

Barbour, M. T., Swietlik, W. F., Jackson, S. K., Courtemanch, D. L., Davis, S. P., \& Yoder, C. O. (2000). Measuring the attainment of biological integrity in the USA: A critical element of ecological integrity. Hydrobiologia, 422-423, 453-464. doi:10.1023/A:1017095003609.

Bauer, D. W. (1998). Streambank erosion and slumping along by Blue Earth River. MS Thesis. St Paul, MN: University of Minnesota.

Bauer, S. B., \& Ralph, S. C. (2001). Strengthening the use of aquatic habitat indicators in clean water act programs. Fisheries, 26(6), 14-25. doi:10.1577/ 1548-8446(2001)026<0014:STUOAH>2.0.CO;2.

Berkman, H. E., \& Rabeni, C. F. (1987). Effect of siltation on stream fish communities. Environmental Biology of Fishes, 18, 285-294. doi:10.1007/BF00004881.

Bledsoe, B. P., Watson, C. C., \& Biedenharn, D. S. (2002). Quantification of incised channel evolution and equilibrium. Journal of the American Water Resources Association, 38, 861-870. doi:10.1111/j.17521688.2002.tb01002.x.

Brezonik, P. L., Easter, K. W., Hatch, L., Mulla, D., \& Perry, J. (1999). Management of diffuse pollution in agricultural watersheds: Lessons from the Minnesota River Basin. Water Science and Technology, 39, 323330. doi:10.1016/S0273-1223(99)00350-9.

Brookes, A. (1988). Channelized rivers: Perspectives for environmental management. Chichester, UK: Wiley. 
Brooks, K. N., Ffolliott, P. F., Gregersen, H. M., \& DeBano, L. F. (2003). Hydrology and the management of watersheds (3rd edn.). Ames, IA: Iowa State Press.

Brouder, M. J. (2001). Effects of flooding on recruitment of rountail chub, Bila robusta, in a southwestern river. The Southwestern Naturalist, 46, 302-310. doi: $10.2307 / 3672426$.

Cairns, J., Jr. (1977). Quantification of biological integrity. In R. K. Ballentine, \& L. J. Guarraia (Eds.), The integrity of water. Proceedings of a symposium, March 10-12, 1975 (pp. 171-187). Washington, DC: US Environmental Protection Agency.

Castella, E., Adalsteinsson, H., Brittain, J. E., Gislason, G. M., Lehmann, A., Lencioni, V., et al. (2001). Macrobenthic invertebrate richness and composition along a latitudinal gradient of European glacier-fed streams. Freshwater Biology, 46, 1811-1831. doi:10. 1046/j.1365-2427.2001.00860.x.

Connell, J. H. (1978). Diversity in tropical rain forests and coral reefs. Science, 199, 1302-1310. doi:10.1126/ science.199.4335.1302.

Cuffney, T. F. (1988). Input, movement and exchange of organic matter within a subtropical coastal black water river-flood plain system. Freshwater Biology, 19, 305320. doi:10.1111/j.1365-2427.1988.tb00353.x.

Death, R. G. (1995). Spatial patterns in benthic invertebrate community structure: Products of habitat stability or are they habitat specific? Freshwater Biology, 33, 455-467. doi:10.1111/j.1365-2427.1995.tb00406.x.

Death, R. G., \& Winterbourn, M. J. (1994). Environmental stability and community persistence: A multivariate perspective. Journal of the North American Benthological Society, 13, 125-139. doi:10.2307/1467232.

Death, R. G., \& Winterbourn, M. J. (1995). Diversity patterns in stream benthic invertebrate communities: The influence of habitat stability. Ecology, 76, 1446-1460. doi:10.2307/1938147.

Duncan, M. J., Suren, A. M., \& Brown, S. L. R. (1999). Assessment of streambed stability in steep bouldery streams: Development of a new analytical technique. Journal of the North American Benthological Society, 18, 445-456. doi:10.2307/1468377.

Feist, M., \& Niemala, S. (2002). Evaluating progress of biological condition in streams of the Minnesota River Basin. St Paul, MN: Biological Monitoring Program, Minnesota Pollution Control Agency.

Fitzpatrick, F. A., Waite, I. R., D'Arconte, P. J., Meador, M. F., Maupin, M. A., \& Gurtz, M. E. (1998). Revised methods for characterizing stream habitat in the national water-quality assessment program. WaterResources Investigations Report 98-4052. Raleigh, NC: US Geological Survey.

Forshay, K. J., \& Stanley, E. H. (2005). Rapid nitrate loss and denitrification in a temperate river floodplain. Biogeochemistry, 75, 43-64.

Frey, D. G. (1977). Biological integrity of water-An historical approach. In R. K. Ballentine \& L. J. Guarria (Eds.), The integrity of water (pp. 127-140). Washington, DC: US Environmental Protection Agency.
Galay, V. J. (1983). Causes of river bed degradation. Water Resources Research, 19, 1057-1090. doi:10.1029/ WR019i005p01057.

Gislason, G. M., Adalsteinsson, H., Hansen, I., Olafsson, J. S., \& Svavarsdottir, K. (2001). Longitudinal changes in macroinvertebrates assemblages along a glacial river system in central Iceland. Freshwater Biology, 46, 1737-1751. doi:10.1046/j.1365-2427.2001.00855.x.

Goldstein, R. M., Lorenz, D. L., \& Niemela, S. (1999). Development of a stream habitat index for use with an index of biotic integrity in the St. Croix River Basin, Minnesota. Water-Resources Investigations Report 99-4290. Mounds View, MN: US Geological Survey.

Goodrich, C., Huggins, D. G., Everhart, R. C., \& Smith, E. F. (2004). Summary of state and national biological assessment methods, physical habitat assessment methods, and biological criteria. Lawrence, KS: Central Plains Center for BioAssessment, Kansas Biological Survey.

Gorman, O. T., \& Karr, J. R. (1978). Habitat structure and stream fish communities. Ecology, 59, 507-515. doi:10.2307/1936581.

Graf, W. L. (2001). Damage control: Restoring the physical integrity of America's rivers. Annals of the Association of American Geographers, 91, 1-27. doi:10.1111/0004-5608.00231.

Harrelson, C. C., Rawlings, C. L., \& Potyondy, J. P. (1994). Stream channel reference sites: An illustrated guide to field techniques, RM-245. US Department of Agriculture, Forest Service, Rocky Mountain Forest and Range Experiment Station.

Hatch, L. K., Mallawatantri, A., Wheeler, D., Gleason, A., Mulla, D., Perry, J., et al. (2001). Land management at the major watershed agroecoregion intersection. Journal of Soil and Water Conservation, 56, 44-51.

Heiber, M., Robinson, C. T., Uehlinger, U., \& Ward, J. V. (2002). Are alpine lake outlets less harsh than other alpine streams? Archiv fuer Hydrobiologie, 154, 199233.

Hooke, J. M. (2004). Cutoffs galore!: Occurrence and causes of multiple cutoffs on a meandering river. Geomorphology, 61, 225-238. doi:10.1016/j.geomorph. 2003.12.006.

Hughes, R. M., Gakstatter, J. H., Shirazi, M. A., \& Omernik, J. M. (1982). An approach for determining biological integrity in flowing waters. In T. B. Brown (Ed.), Place resource inventories: Principles and practices, a national workshop (pp. 877-888). Bethesda, MD: Society of American Foresters.

Izaac Walton League of America (IWLA) (2006). A handbook for stream enhancement and stewardship (2nd edn.). Granville, OH: McDonald \& Woodward.

Junk, W. J., Bayley, P. B., \& Sparks, R. E. (1989). The flood pulse concept in river floodplain systems. Canadian Special Publication of Fisheries and Aquatic Sciences, 106, 110-127.

Karr, J. R. (1981). Assessment of biotic integrity using fish communities. Fisheries, 6(6), 21-27. doi:10.1577/ 1548-8446(1981)006<0021:AOBIUF>2.0.CO;2. 
Karr, J. R. (1993). Defining and assessing ecological integrity beyond water quality. Environmental Toxicology and Chemistry, 12, 1521-1531. doi:10.1897/ 1552-8618(1993)12[1521:DAAEIB]2.0.CO;2.

Karr, J. R. (1999). Defining and measuring river health. Freshwater Biology, 41, 221-234. doi:10.1046/j.13652427.1999.00427.x.

Karr, J. R., \& Chu, E. W. (1999). Restoring life in running waters: Better biological monitoring. Washington DC: Island Press.

Karr, J. R., \& Dudley, D. R. (1981). Ecological perspective on water quality goals. Environmental Management, 5 , 55-68. doi:10.1007/BF01866609.

Kaufmann, P. R. (1993). Physical habitat. In R. M. Huges (Ed.), Stream indicator and design workshop. EPA/ 600/R-93/138 (pp. 59-69). Corvallis, OR: US Environmental Protection Agency.

Kaufmann, P. R., \& Robison, E. G. (1998). Field operations and methods for measuring the ecological condition of wadeable streams, section 7: Physical habitat characterization. EPA/620/R-94/004F. Research Triangle Park, NC: US Environmental Protection Agency.

Kaufmann, P. R., Levine, P., Robison, E. G., Seeliger, C., \& Peck, D. V. (1999). Quantifying physical habitat in wadeable streams. EPA/620/R-99/003. Washington, DC: US Environmental Protection Agency.

Kaufmann, P. R., Faustini, J. M., Larsen, D. P., \& Shirazi, M. A. (2008). A roughness-corrected index of relative bed stability for regional stream surveys. Geomorphology, 99, 150-170. doi:10.1016/j.geomorph.2007.10.007.

Kline, M., Alexander, C., Pomeroy, S., Jaquith, S., Springston, G., Cahoon, B., et al. (2004). Remote sensing and field survey techniques for conducting watershed and reach level assessments. Stream Geomorphic Assessment - Protocol Handbooks. Waterbury, VT: Vermont Agency of Natural Resources.

Lambe, W. T. (1951). Soil testing for engineers. New York: Wiley.

Lane, E. W. (1955). The importance of fluvial morphology in hydraulic engineering. American Society of Civil Engineers Proceedings, 81,1-17.

Lau, J. K., Lauer, T. E., \& Weinman, M. L. (2006). Impacts of channelization on stream habitats and associated fish assemblages in East Central Indiana. American Midland Naturalist, 156, 319-330. doi:10.1674/00030031(2006)156[319:IOCOSH]2.0.CO;2.

Lenat, D. R., Penrose, D. L., \& Eagleson, K. S. (1981). Variable effects of sediment addition on stream benthos. Hydrobiologia, 79, 187-194. doi:10.1007/ BF00006126.

Lenhart, C. F. (2008). The influence of watershed hydrology and stream geomorphology on turbidity, sediment and nutrients in tributaries of the Blue Earth River, Minnesota, USA. Ph.D. Dissertation, St Paul, MN: University of Minnesota.

Leopold, L. B., \& Maddock, T. M., Jr. (1953). The hydraulic geometry of stream channels and some physiographic implications. In United States geological survey professional paper, p. 252.
Lisle, T. E., \& Hilton, S. (1999). Fine bed material in pools of natural gravel-bed channels. Water Resources Research, 35, 1291-1304. doi:10.1029/1998WR900088.

Lisle, T. E., Nelson, J. M., Pitlick, J. P., Madej, M. A., \& Barkett, B. L. (2000). Variability of bed mobility in natural, gravel-bed channels and adjustments to sediment load at local and reach scales. Water Resources Research, 36, 3743-3755. doi:10.1029/2000WR900238.

Lods-Crozet, B., Lencioni, V., Olafsson, J. S., Snook, D. L., Velle, G., Brittain, J. E., et al. (2001a). Chironomid (Diptera: Chironomidae) communities in six European glacier-fed streams. Freshwater Biology, 46, 1791-1809. doi:10.1046/j.1365-2427.2001.00859.x.

Lods-Crozet, B., Castella, E., Cambin, D., Ilg, C., Knispel, S., \& Mayor-Simeant, H. (2001b). Macroinvertebrate community structure in relation to environmental variables in a Swiss glacial stream. Freshwater Biology, 46, 1641-1661. doi:10.1046/j.1365-2427.2001. 00850.x.

Maddock, I. (1999). The importance of physical habitat assessment for evaluating river health. Freshwater Biology, 41, 373-391. doi:10.1046/j.1365-2427. 1999.00437.x.

Magner, J. A., \& Brooks, K. N. (2007). Stratified regional hydraulic geometry curves: A tool for managing riparian connectivity and water quality. Hydrologic Science and Technology, 23, 159-172.

Magner, J. A., \& Brooks, K. N. (2008). Predicting stream channel erosion in the lacustrine core of the upper Nemadji River, Minnesota (USA) using stream geomorphology metrics. Environmental Geology, 54, 1423-1434. doi:10.1007/s00254-007-0923-3.

Magner, J. A., \& Steffen, L. J. (2000). Stream morphological response to climate and land-use in the Minnesota River Basin. Joint Conference on Water Resources Engineering, Planning and Management. doi:10.1061/ 40517(2000)74 Retrieved 25 October 2007 from http:// scitation.aip.org/getabs/servlet/GetabsServlet?prog= normal\&id=ASCECP000104040517000074000001\& idtype $=$ cvips $\&$ gifs $=$ yes

Magner, J. A., Baird, O., \& Kuehner, K. J. (2004a). Ground water pore-pressure influences on stream restoration. In Proceedings of self-sustaining solutions for streams, wetlands, and watersheds. American Society of Agricultural and Biological Engineers. St Joseph, Michigan. Retrieved 15 February 2007 from http://asae.frymulti.com/abstract.asp?aid= $17375 \& \mathrm{t}=2$.

Magner, J. A., Payne, G. A., \& Steffen, L. J. (2004b). Drainage effects on stream nitrate-N and hydrology in south-central Minnesota (USA). Environmental Monitoring and Assessment, 91, 183-198. doi:10.1023/B:EMAS.0000009235.50413.42.

Maiolini, B., \& Lencioni, V. (2001). Longitudinal distribution of macroinvertebrate assemblages in a glacially influence stream system in the Italian Alps. Freshwater Biology, 46, 1625-1639. doi:10.1046/j.13652427.2001.00849.x.

Maul, J. D., Farris, J. L., Milam, C. D., Cooper, C. M., Testa, S., III, \& Feldman, D. L. (2004). The influence 
of stream habitat and water quality on macroinvertebrate communities in degraded streams of northwest Mississippi. Hydrobiologia, 518, 79-94. doi:10.1023/ B:HYDR.0000025058.00605.6e.

McIntosh, A. R. (2000). Habitat- and size-related variations in aquatic trout impacts on native Galaxiid fishes in New Zealand streams. Canadian Journal of Fisheries and Aquatic Sciences, 57, 2140-2151. doi:10.1139/ cjfas-57-10-2140.

Montgomery, D. R., \& MacDonald, L. H. (2002). Diagnostic approach to stream channel assessment and monitoring. Journal of the American Water Resources Association, 38, 1-16. doi:10.1111/j.17521688.2002.tb01530.x.

Nerbonne, B. A., \& Vondracek, B. (2001). Effects of local land use on physical habitat, benthic macroinvertebrates, and fish in the Whitewater River, Minnesota, USA. Environmental Management, 28, 8799. doi:10.1007/s002670010209.

Natural Resources Conservation Service (NRCS) (1988). Erosion and sedimentation in the Nemadji River Basin: Nemadji River Basin final report. Duluth, MN: US Forest Service, Natural Resources Conservation Service.

Natural Resources Conservation Service (NRCS) (2007). Regional hydraulic geometry curves. US Department of Agriculture, Natural Resources Conservation Service. Retrieved 18 August 2007 from http://wmc.ar. nrcs.usda.gov/technical/HHSWR/Geomorphic/.

Ohio Environmental Protection Agency (Ohio EPA) (2007). Total Maximum Daily Loads for the Olentangy River Watershed. Final Report. Columbus, OH: Division of Surface Water.

Peck, D. V., Herlihy, A. T., Hill, B. H., Hughes, R. M., Kaufmann, P. R., Klemm, D. J., et al. (2006). Environmental monitoring and assessment program Surface waters western pilot study: Field operations manual for wadeable streams. EPA-620-R-06/003. Washington, DC: Office of Research and Development.

Petts, G., \& Foster, I. (1985). Rivers and landscape. London, UK: Edward Arnold.

Pfankuch, D. J. (1975). Stream reach inventory and channel stability evaluation. Missoula, MT: Region 1, US Department of Agriculture Forest Service.

Pitt, R. E., Field, R., Lalor, M., \& Brown, M. (1995). Urban stormwater toxic pollutants-assessment, sources, and treatability. Water Environment Research, 67, 260-275. doi:10.2175/106143095X131466.

Poff, N. L., Tokar, S., \& Johnson, P. (1996). Stream hydrological and ecological responses to climate change assessed with an artificial neural network. Limnology and Oceanography, 41, 857-863.

Rabeni, C. F. (2000). Evaluating physical habitat integrity in relation to the biological integrity of streams. $\mathrm{Hy}$ drobiologia, 42-43, 331-342.

Rabeni, C. F., \& Jacobsen, R. B. (1993). Geomorphic and hydraulic influences on the abundance and distribution of stream centarchids in Ozark USA streams. Polskie Archiwum Hydrobiologii, 40, 87-99.

Rankin, E. T. (1989). The Qualitative Habitat Evaluation Index (QHEI): Rationale, methods, and application.
Columbus, OH: Division of Water Quality Planning and Assessment, Ohio EPA.

Rapport, D. J., Gaudet, C., Karr, J. R., Baron, J. S., Bohlen, C., Jackson, W., et al. (1998). Evaluating landscape health: Integrating societal goals and biophysical processes. Journal of Environmental Management, 53, 1-15. doi:10.1006/jema.1998.0187.

Reid, L. M., \& Hilton, S. (1998). Buffering the buffer. General Technical Report PSW-GTR-168. Washington, DC: USDA Forest Service.

Resh, V. H., Brown, A. V., Covich, A. P., Gurtz, M. E., Li, H. W., Minshall, G. W., et al. (1988). The role of disturbance in stream ecology. Journal of the North American Benthological Society, 7, 433-455.

Riedel, M. S., Verry, E. S., \& Brooks, K. N. (2005). Impacts of land use conversion on bankfull discharge and mass wasting. Journal of Environmental Management, 76, 326-337. doi:10.1016/j.jenvman.2005.02.002.

Robertson, A. L., \& Milner, A. M. (1999). Meiobenthic arthropod communities in new streams in Glacier Bay National Park, Alaska. Hydrobiologia, 397, 197-209. doi:10.1023/A:1003782323718.

Rosgen, D. (1996). Applied river morphology. Pagoda Springs, CO: Wildland Hydrology.

Rosgen, D. (2006). A Watershed Assessment for River Stability and Sediment Supply (WARSSS). Fort Collins, CO: Wildland Hydrology.

Ross, S. T., O’Connell, M. T., Patrick, D. M., Latorre, C. A., Slack, W. T., Knight, J. G., et al. (2001). Stream erosion and densities of Etheostoma rubrum (Percidae) and associated riffle-inhabiting fishes: Biotic stability in a variable habitat. Copeia, 4, 916-927. doi:10.1643/0045-8511(2001)001[0916:SEADOE]2.0. $\mathrm{CO} ; 2$.

Rounick, J. S., \& Winterbourn, M. J. (1982). Benthic faunas of forested streams. New Zealand Journal of Ecology, $5,140-150$.

Schlosser, I. J. (1987). A conceptual framework for fish communities in small warmwater streams. In W. J. Matthews, \& D. C. Heins (Eds.), Community and evolutionary ecology of North American stream fishes (pp. 17-24). Norman, OK: University of Oklahoma.

Schumm, S. A. (1977). The fluvial system. Caldwell, NJ: The Blackburn Press.

Schumm, S. A., Harvey, M. D., \& Watson, C. C. (1984). Incised channels: Morphology, dynamics, and control. Littleton, CO: Water Resources Publications.

Shields, F. D., Jr., Knight, S. S., \& Cooper, C. M. (1994). Effects of channel incision on base flow stream habitats and fishes. Environmental Management, 18, 43-57. doi:10.1007/BF02393749.

Simon, A. (1989). The discharge of sediment in channelized alluvial streams. Water Resources Bulletin, 25, 11771188.

Simon, A., \& Downs, P. W. (1995). An interdisciplinary approach to evaluation of potential instability in alluvial channels. Geomorphology, 12, 215-232. doi:10.1016/0169-555X(95)00005-P.

Simon, A., \& Rinaldi, M. (2000). Channel instability in the loess area of the midwestern United States. Journal 
of the American Water Resources Association, 36, 133150. doi:10.1111/j.1752-1688.2000.tb04255.x.

Simon, A., Pollen, N. L., \& Langendoen, E. J. (2006). Influence of two woody riparian species on critical conditions for streambank stability: Upper Truckee River, California. Journal of the American Water Resources Association, 42, 99-113. doi:10.1111/j.17521688.2006.tb03826.x.

Simon, A., Doyle, M., Kondolf, M., Shields, F. D., Jr., Rhoads, B., \& McPhillips, M. (2007). Critical evaluation of how the Rosgen classification and associated "natural channel design" methods fail to integrate and quantify fluvial processes and channel response. Journal of the American Water Resources Association, 43, 1117-1131. doi:10.1111/j.1752-1688.2007.00091.x.

Sorenson, S. K., Porter, S. D., Akers, K. K. B., Harris, M. A., Kalkhoff, S. J., Lee, K. E., et al. (1999). Water quality and habitat conditions in upper Midwest streams relative to riparian vegetation and soil characteristics. August 1997-study design, methods, and data. OpenFile Report 99-202, Mounds View, MN: US Geological Survey.

Southwood, T. R. E. (1977). Habitat, the templet for ecological strategies? Journal of Animal Ecology, 46, 337365. doi:10.2307/3817.

Sullivan, S. M. P., Watzin, M. C., \& Hession, W. C. (2006). Influence of stream geomorphic condition on fish communities in Vermont, USA. Freshwater Biology, 51, 1811-1826. doi:01616.x01616.x.

Thoma, D. P., Gupta, S. C., Bauer, M. E., \& Kirchoff, C. E. (2005). Airborne laser scanning for riverbank erosion assessment. Remote Sensing of Environment, 95, 493501. doi:10.1016/j.rse.2005.01.012.

Thorne, C. R., Hey, R. D., \& Newson, M. D. (1997). Applied fluvial geomorpholgy for river engineering and management. Chichester, UK: Wiley.

Tipton, J. A., Bart, H. L., Jr., \& Piller, K. R. (2004). Geomorphic disturbance and its impact on darter (Teleostomi: Percidae) distribution and abundance in the Pearl River drainage, Mississippi. Hydrobiologia, 527, 49-61. doi:10.1023/B:HYDR.0000043181. 40585.ef.

Townsend, C. R., Scarsbrook, M. R., \& Doledec, S. (1997a). The intermediate disturbance hypothesis, refugia, and biodiversity in streams. Limnology and Oceanography, 42, 938-949.

Townsend, C. R., Scarsbrook, M. R., \& Doledec, S. (1997b). Quantifying disturbance in streams: Alternative measures of disturbance in relation to macroinvertebrate species traits and species richness. Journal of the North American Benthological Society, 16, 531534. doi:10.2307/1468142.

Trimble, S. W. (1997). Contribution of stream channel erosion to sediment yield from an urbanizing watershed. Science, 278, 1442-1444. doi:10.1126/science.278. 5342.1442.

Trimble, S. W., \& Mendel, A. C. (1995). The cow as a geomorphic agent: A critical review. Geomorphology, 13, 233-253. doi:10.1016/0169-555X(95)00028-4.
Upham, W. (1969). Minnesota geographic names: Their origin and historic significance. St Paul, MN: Minnesota Historical Society.

US Environmental Protection Agency (USEPA) (1990). National water quality inventory: 1988 report to Congress. EPA Report 440-4-90-003. Washington, DC: Office of Water.

US Environmental Protection Agency (USEPA) (1992). National water quality inventory: 1990 report to Congress. EPA Report 503/9-92/006. Washington, DC: Office of Water.

US Environmental Protection Agency (USEPA) (1995). National water quality inventory: 1994 report to Congress. EPA Report 841-R-95-005. Washington, DC: Office of Water.

US Environmental Protection Agency (USEPA) (1997). Urbanization and streams-studies of hydrologic impacts. EPA Report 841-R-97-009. Washington, DC: Office of Water.

US Environmental Protection Agency (USEPA) (1998). National water quality inventory: 1996 report to Congress. EPA Report 841-R-97-008. Washington, DC: Office of Water.

US Environmental Protection Agency (USEPA) (2000a). Stressor identification guidance document. EPA Report 822-B-00-025. Washington, DC: Office of Water and Office of Research and Development.

US Environmental Protection Agency (USEPA) (2000b). National water quality inventory: 1998 report to Congress. EPA Report 841-F-00-006. Washington, DC: Office of Water.

US Environmental Protection Agency (USEPA) (2002). National Water Quality Inventory: 2000 Report to Congress. EPA Report 841-F-02-003. Washington, DC: Office of Water.

US Environmental Protection Agency (USEPA) (2007). National water quality inventory: 2002 report to Congress. EPA Report 841-R-07-001. Washington, DC: Office of Water.

US Geological Survey (USGS) (1982). Guidelines for determining flood flow frequency. Bulletin No. $17 \mathrm{~B}$. Reston, VA: Hydrology Subcommittee.

Vondracek, B., Blann, K. L., Cox, C. B., Frost Nerbonne, J. A., Mumford, K. G., Nerbonne, B. A., et al. (2005). Land use, spatial scale, and stream systems: Lessons from an agricultural region. Environmental Management, 36, 775-791. doi:10.1007/s00267-0050039-z.

Waters, T. F. (1995). Sediment in streams: Sources, biological effects and control. Monograph 7. Bethesda, MD: American Fisheries Society.

Watson, C. C., Biedenharn, D. S., \& Bledsoe, B. P. (2002). Use of incised channel evolution models in understanding rehabilitation alternatives. Journal of the American Water Resources Association, 38, 151-160. doi:10.1111/j.1752-1688.2002.tb01542.x.

Whittier, T. R., Larsen, D. P., Hughes, R. M., Rohm, C. M., Gallant, A. L., \& Omernik, J. M. (1987). The Ohio stream regionalization project: A compendium 
of results. EPA-600-3-87-025. Corvallis, OR: Environmental Research Laboratory, US Environmental Protection Agency.

Winterbourn, M. J., \& Collier, K. J. (1987). Distribution of benthic invertebrates in acid, brown water streams in the South Island of New Zealand. Hydrobiologia, 153, 277-286.
Wolman, M. G. (1954). A method of sampling coarse river-bed material. Transactions-American Geophysical Union, 35, 951-956.

Wolman, M. G., \& Leopold, L. B. (1957). River flood plains: Some observations on their formation. Professional Paper 282-C. Washington, DC: US Geological Survey. 